\title{
HTR2A Gene
}

National Cancer Institute

\section{Source}

National Cancer Institute. HTR2A Gene. NCI Thesaurus. Code C39775.

This gene plays a role in G protein-coupled receptor signal transduction and sterol

metabolism. 